\title{
The Potential Use of Arbuscular Mycorrhiza in the Cultivation of Medicinal Plants in Barak Valley, Assam: A Review
}

\author{
DHRITIMAN CHANDA ${ }^{1}$, G.D. SHARMA ${ }^{2}$, D.K. JHA ${ }^{3}$ and MOHAMED HIJRI ${ }^{4}$ \\ ${ }^{1}$ Microbiology Laboratory, Department of Life Sciences and Bioinformatics, \\ Assam University,Silchar,India. \\ ${ }^{2}$ Vice-Chancellor, Bilaspur University, Chattisgarh, India. \\ ${ }^{3}$ Department of Botany, Gauhati University, Guwahati, India. \\ ${ }^{4}$ Institut De Recherche En Biologie Vegetale, University De Montreal, Montreal, Canada.
}

http://dx.doi.org/10.12944/CWE.9.2.40

(Received: Feburary 26, 2014; Accepted: April 06, 2014)

\begin{abstract}
AM fungi are widespread and are found from arctic to tropics in most agricultural and natural ecosystems. They play an important role in plant growth, health and productivity. They increase seedling tolerance to drought, high temperatures, toxic heavy metals, high or low $\mathrm{pH}$ and even extreme soil acidity. The cultivation of medicinal and herbal plants has assumed greater importance in recent years due to their tremendous potential in modern and traditional medicine. They are also used as raw materials for pharmaceutical, cosmetic and fragrance industries. Indian system of medicine (ISM) uses 25,000 species belonging to more than 1000 genera. About $25 \%$ species are used by the industries. The Barak Valley is the southernmost part of the Assam and consists of three districts namely Cachar, Karimganj and Hailakandi. Different tribes staying here are directly using of medicinal plants for the treatments of different ailments. Comparatively very less attention has been given for the conservation of some of these rare and endangered medicinal plants which are extensively used by the tribes of Assam. So, AM fungi can play an effective role in the conservation of some valuable medicinal plants where Glomus sp. was found to be widely used for the increase yield of important medicinal plants. This review summarizes the data from recent studies to elucidate the potential use of AM fungi for promoting growth and disease resistance in medicinal plants found in southern part of Assam, which in turn provide a natural enhancer for the commercial production of traditional drugs from various important plants.
\end{abstract}

Key words: Arbuscular mycorrhiza; Medicinal plants; Traditional drugs, Barak Valley, Bioremediation.

\section{INTRODUCTION}

Arbuscular Mycorrhizal(AM) fungi interact either directly with other soil organisms or they may influence these organisms indirectly by affecting host physiology that could change root morphology, physiology and patterns of exudation into the mycorrhizosphere. Mycorrhizae form mutualistic symbiotic relationships with plant roots of more than $80 \%$ of land plants including many important crops and forest tree species ${ }^{1,2}$. Seven kinds of mycorrhiza: arbutoid mycorrhiza, ectomycorrhiza, endomycorrhiza or arbuscular mycorrhiza, ect- endomycorrhiza, ericoid mycorrhiza, monotropoid mycorrhiza, and orchidoid mycorrhiza have been recognized ${ }^{3-5}$. However, AM fungi are most commonly found in the rhizosphere roots of a wide range of herbaceous and woody plants ${ }^{6}$.

The plant roots provide substances for the fungi and the fungi transfer nutrients and water to the plant roots 7,8 . Endomycorrhizal fungi are inter and intracellular and penetrate the root cortical cells and form finger like branched structures called arbuscule and vesicles to be known as vesicular arbuscular mycorrhiza (VAM). In some cases no vesicles 
are formed and they are known as arbuscular mycorrhiza (AM) ${ }^{9}$.Arbuscular Mycorrhiza (AM) mycobionts forming symbiosis with approximately $90 \%$ (>200000) of the terrestrial plant communities. They are essential components of soil biota and are found in almost all ecological situations particularly those supporting plant communities with high species diversity ${ }^{10}$.So far more than 170 species of AM fungi have been recorded and described ${ }^{11}$.AM fungi belong to nine genera: Acaulospora, Archaeospora, Enterophospora, Gerdemannia, Geosiphon, Gigaspora, Glomus, Paraglomus, and Scutellospora ${ }^{12,13 .}$

\section{Benefits of AM fungi with the host plant}

AM fungi are a widespread group and are found from the arctic to tropics and are present in most agricultural and natural ecosystems. They play an important role in plant growth, health and productivity ${ }^{14}$. AM fungi help plants to absorb nutrients, especially the less available mineral nutrients such as copper, molybdenum, phosphorus and zinc ${ }^{15}$.They increase seedling tolerance to drought, high temperatures, toxic heavy metals, high or low $\mathrm{pH}$ and even extreme soil acidity ${ }^{8,16}$. AM fungi can reduce the severity of soil-borne pathogens and enhance resistance in roots against root rot disease ${ }^{17,18}$. Competition between mycorrhizal fungi and pathogenic fungi of the same root tissues and production of fungistatic compounds results in protection of mycorrhizal seedlings ${ }^{19,20}$. AM fungi have been shown to have benefits to host plants by increasing herbivore tolerance, pollination, soil stability, and heavy metal tolerance. The use of AM fungi as biofertilizers is not new, they have been produced for the use in agriculture, horticulture, landscape restoration, and soil remediation for almost two decades ${ }^{21}$. Mass production of AM fungi has been achieved with several species such as Acaulospora laevis, Glomus. clarum, G. etunicatum, G. intraradices, G. mosseae, Gigaspora ramisporophora and Gigaspora rosea but Glomus intraradices is the most common inoculum of endomycorrhizae products ${ }^{22}$..Effective management of AM fungi involves increasing population of propagules such as spores, colonized root fragments and hyphae using host plants and also by adoption soil management techniques ${ }^{1,23}$.

\section{The traditional medicinal plants and the use of AM fungi}

The cultivation of medicinal and herbal plants has assumed greater importance in recent years due to their tremendous potential in modern and traditional medicine. They are also used as raw materials for pharmaceutical, cosmetic and fragrance industries. Indian system of medicine (ISM) uses 25,000 species belonging to more than 1000 genera. About $25 \%$ species are used by the industries. The criteria for selecting AM fungi will depend on the climate soil and host medicinal plants. The AM fungi must 1) colonize roots rapidly after inoculation, 2) absorb phosphate from the soil, 3) transfer phosphorus to the plant, 4) increase plant growth, 5) persist in soil and reestablish mycorrhizal symbiosis during the following seasons and 6) form propagules that remain viable during and after inoculum production ${ }^{24}$.

Inoculation of AM fungi during an early stage of acclimatization process has become an alternative strategy for better establishment by improving the plant growth. The AM fungal association had not only enhanced the growth of medicinal plants but also improved the productivity of medicinal compounds. Hence, there is a need for research in improving the quality and quantity of drugs produced from native medicinal plants in relatively shorter period and at lower expense by using AM fungi ${ }^{25}$. AM fungi are also responsible for enhanced uptake of mineral nutrients especially phosphorus from the soil by the host plants and thereby enhancing vigor ${ }^{26}$.

Traditional herbal medicines are increasingly being used not only by the developing countries but also by the developed countries in their primary health care system. A bulk of our rural population relies on the drug resources of plant origin. Thus, the cultivation of medicinal plants is increasing steadily to maintain a regular supply and to support their increasing demand. But corresponding research works on the occurrence of AM fungi and their associations in medicinal plants have received very little attention as compared to the studies on forest species and field crops. Out of 150 naturally growing and frequently used medicinal plants, 24 plant species have been found to be on extinction due to over-exploitation for medicinal purposes, particularly 
used by local tribes of Barak Valley. Among various medicinal plants, Cassia fistula, C. tora, Caeselpinea pulcherima, Melastoma malabatricum, Acacia nilotica, Shorea robusta, Artocarpus sp., Tectona grandis, Dillenia pentagyna ,Albezzia lebbeck are very important medicinal plants which are necessary to conserve for their various traditional as well as commercial medicinal values (Table 1$)^{27}$. Thus, it is essential to have a proper use of AM fungi in the cultivation of medicinal plants and thus to develop a protocol for traditional drugs in pharmaceutical, cosmetic and fragrance industries.

\section{Interaction of AM fungi with the Medicinal} Plants

Mycorrhizal colonization resulted in increased accumulation of nutrients, chlorophyll, carotenoids, sugars and proteins. This was further confirmed from the presence of spores belonging to different VAM fungal species in the rhizosphere soils. VAM inoculation significantly increased the uptake of $\mathrm{N}, \mathrm{P}$ and, but most markedly increased of $\mathrm{P}$ uptake. The effects of inoculation with vesicular arbuscular mycorrhizal (VAM) fungus Glomus fasciculatum on the root colonization, growth, essential oil yield and nutrient acquisition in three cultivars of menthol mint

Table 1: Traditional uses of some Medicinal important plants of Barak Valley ${ }^{27}$

\begin{tabular}{|c|c|c|}
\hline Plant & Family & Uses \\
\hline Achyranthes aspera & Amaranthaceae & $\begin{array}{l}\text { Leaf juice extract used internally in otorrh ea, young } \\
\text { twig paste used as bandage in external wounds } \\
\text { and injury. }\end{array}$ \\
\hline Cassia fistula & Fabaceae & $\begin{array}{l}\text { The leaves are employed there for erysipelas, malaria, } \\
\text { rheumatism, and ulcers. In Brazilian herbal medicine, } \\
\text { the seeds are used as a laxative and the leaves and } \\
\text { bark is used for pain and inflammation. }\end{array}$ \\
\hline $\begin{array}{l}\text { Caesalpinia } \\
\text { pulcherrima }\end{array}$ & Caesalpiniaceae & $\begin{array}{l}\text { Plant pacifies vitiated kapha, pitta, fever, jaundice, colic, } \\
\text { flatulence, malignant tumors. It is a proven } \\
\text { anti-cancerous drug. }\end{array}$ \\
\hline Acacia nilotica & Fabaceae & $\begin{array}{l}\text { Acts as an astringent and It is used to treat diarrhoea, } \\
\text { dysentery, and leprosy. Bark and root decoction, said to } \\
\text { impart courage, even aphrodisia, and the root is said to } \\
\text { cure impotence. The bruised leaves are poultice and } \\
\text { used to treat ulcers. }\end{array}$ \\
\hline Dillenia pentagyna & Dilleniaceae & $\begin{array}{l}\text { Plants are used in the treatment of anal fistula, wounds, } \\
\text { diabetes, diabetic carbuncle, neuritis, pleurisy, } \\
\text { pneumonia, and burning sensation. }\end{array}$ \\
\hline Tectona grandis & Verbenaceae & $\begin{array}{l}\text { Plants are used for inflammation, burning sensation, } \\
\text { skin diseases, diabetes, stomatitis, ulcers, hemorrhages, } \\
\text { urinary retention, kidney diseases, urinary calculi } \\
\text { and arthritis. }\end{array}$ \\
\hline $\begin{array}{l}\text { Melastoma } \\
\text { melabatricum }\end{array}$ & Melastomaceae & $\begin{array}{l}\text { The seeds are used to produce a black dye, the roots, } \\
\text { a pink dye Traditionally, Leaves are used to treat } \\
\text { diarrhoea and dysentery wash for ulcers, to prevent } \\
\text { scarring from smallpox and to treat piles. }\end{array}$ \\
\hline Terminalia arjuna & Combretaceae & $\begin{array}{l}\text { Bark,young stem \& leaf extract is used as cardiotonic, } \\
\text { in high blood pressure and liver complaints. }\end{array}$ \\
\hline Rauvolfia serpentina & Apocynaceae & $\begin{array}{l}\text { Leaf juice is used for curing and controlling high } \\
\text { blood pressure. }\end{array}$ \\
\hline Artocarpus chama & Moraceae & $\begin{array}{l}\text { Bark extract used in jaundice; dried fruit powder } \\
\text { is used in stomach troubles. }\end{array}$ \\
\hline
\end{tabular}


(Mentha arvensis); Kalka, Shivalik and Gomti was found significantly higher as observed by different workers ${ }^{28}$.

It was clearly evident from the data as discussed by different workers that the root systems of all medicinal plant species grown in both control and VAM fungus infested soils were invariably found to harbour VAM association. The VAM colonization and growth response of $G$. fasciculatum was observed in all the four medicinal plants .In the VAM inoculated plants, the percentage of VAM associations were observed significantly higher than the control one. In the inoculated plants, the percent VAM association were significantly higher from 10 to $65 ; 20$ to $85 \%, 12$ to $58 \% ; 15$ to $75 \%$ in the tested plants O.Sanctum, Catharanthus roseus; Coleus forskholii and Cympbopogon flexuosus respectively ${ }^{25}$. The Mycorrhizal root intensity of Vesicles and arbuscules were also recorded higher in the inoculated plants than the control ones (Table 2) 29,30 .

Medicinal plants inoculated with VAM fungus have shown improved growth and development as compared to control plants. The significant increase was observed not only in AM colonization but also in biomass production (dry wt. of root and shoot) due to inoculation with Glomus fasciculatum in all the four medicinal plants. The root and shoot

Table 2: Intensity of VAM formation of some medicinal plants with Glomus fasciculatum ${ }^{25}$

\begin{tabular}{|c|c|c|c|c|c|c|}
\hline \multirow{4}{*}{ Plant } & \multicolumn{6}{|c|}{ VAM status } \\
\hline & \multicolumn{3}{|c|}{ Control plants } & \multicolumn{3}{|c|}{ VAM inoculated plants } \\
\hline & \multirow{2}{*}{$\begin{array}{c}\% \\
\text { VAM } \\
\text { association }\end{array}$} & \multicolumn{2}{|c|}{$\begin{array}{l}\text { Intensity \% } \\
\text { of formation }\end{array}$} & \multirow{2}{*}{$\begin{array}{c}\% \\
\text { VAM } \\
\text { association }\end{array}$} & \multicolumn{2}{|c|}{$\begin{array}{r}\text { Intensity \% } \\
\text { of formation }\end{array}$} \\
\hline & & Vesicles & Arbuscules & & Vesicles & Arbuscules \\
\hline Ocimum sanctum & $10 \pm 1.5$ & $12 \pm 0.75$ & $10 \pm 1.0$ & $65 \pm 1.0$ & $60 \pm 1.5$ & $40 \pm 2.0$ \\
\hline Catharanthus roseus & $20 \pm 1.5$ & $20 \pm 0.5$ & $12 \pm 0.5$ & $85 \pm 2.5$ & $70 \pm 1.5$ & $30 \pm 1.5$ \\
\hline Coleus forskholii & $12 \pm 0.5$ & $10 \pm 0.5$ & $8 \pm 1.5$ & $58 \pm 1.5$ & $58 \pm 1.5$ & $42 \pm 2.5$ \\
\hline Cympbopogon flexuosus & $15 \pm 1.0$ & $19 \pm 0.5$ & $11 \pm 0.5$ & $75 \pm 3.5$ & $65 \pm 1.5$ & $35 \pm 2.5$ \\
\hline
\end{tabular}

Values are mean of three replicates \pm SD.

Table 3: Effect of G. fasciculatum inoculation on the shoot and root weight dry protein content and total chlorophyll of medicinal plants ${ }^{25}$

\begin{tabular}{|c|c|c|c|c|c|c|c|c|}
\hline \multirow{3}{*}{ Plant } & \multicolumn{8}{|c|}{ VAM status } \\
\hline & \multirow[b]{2}{*}{$\begin{array}{l}\text { Shoot dry } \\
\text { wt(g/plant) }\end{array}$} & \multicolumn{5}{|c|}{ Control Plants } & \multicolumn{2}{|c|}{$\begin{array}{c}\text { VAM } \\
\text { inoculated plants }\end{array}$} \\
\hline & & $\begin{array}{r}\text { Root dry } \\
\text { wt (g/plan }\end{array}$ & $\begin{array}{l}\mathrm{PC} \text { (mg/g } \\
\text { ) of plant) }\end{array}$ & $\begin{array}{l}\text { TCC (mg } \\
\text { /g plant) }\end{array}$ & $\begin{array}{l}\text { Shoot dry } \\
\text { wt(g/plant) }\end{array}$ & $\begin{array}{l}\text { Root dry } \\
\text { wt(g/plant) }\end{array}$ & $\begin{array}{l}\text { PC (mg/ } \\
\text { g plant) }\end{array}$ & $\begin{array}{l}\text { TCC (mg } \\
\text { /g plant) }\end{array}$ \\
\hline Ocimum sanctum & 12.44 & 7.64 & 60.40 & 1.20 & 18.44 & 11.04 & 80.20 & 2.20 \\
\hline $\begin{array}{l}\text { Catharanthus } \\
\text { roseus }\end{array}$ & 15.66 & 8.44 & 70.66 & 1.90 & 25.22 & 14.98 & 94.00 & 3.40 \\
\hline Coleus forskholii & 8.00 & 5.66 & 53.40 & 1.00 & 15.91 & 10.00 & 79.27 & 1.96 \\
\hline $\begin{array}{l}\text { Cympbopogon } \\
\text { flexuosus }\end{array}$ & 13.00 & 8.00 & 65.20 & 1.50 & 20.10 & 15.20 & 84.00 & 2.60 \\
\hline$C D(p=0.05)$ & 1.52 & 1.64 & 3.56 & 0.34 & 1.58 & 1.54 & 4.24 & 0.34 \\
\hline SD & 0.74 & 0.84 & 7.92 & 0.96 & 3.64 & 3.72 & 8.72 & 0.98 \\
\hline
\end{tabular}

$\mathrm{PC}=$ Protein content, $\mathrm{TCC}=$ Total chlorophyll content, $\mathrm{CD}=$ Critical differences, $\mathrm{SD}=\mathrm{Standard}$ deviation . 
biomass of the inoculated plants were found to be maximum and significant than that of control in all the four medicinal plant species. The reason may be due to the formation of external mycelium around the roots by VAM fungi. Similar improved growth response was also observed in 10 medicinal plants when inoculated with three AM fungal species ( $G$. mossae, G. fasciculatum and G. monosporum) for their efficiency ${ }^{31}$.

The inoculation with $G$. fasciculatum resulted in increased total chlorophyll content and protein content in all the four medicinal plants over control plant. The highest chlorophyll and protein content was recorded in $C$. roseus, followed by C. flexuosus, $O$. sanctum and $C$. forskholii. The increase in total chlorophyll content and protein content in inoculated plants may be due to increased uptake of phosphorus, which will increase the photosynthetic activity of the plants and ultimately the chlorophyll content in plants. Similar findings were reported already by different workers who found that plants inoculated with mycorrhiza showed significant increase in the growth over nonmycorrhizal plants and also had higher percent of phosphorus over non-mycorrhizal plants after six months field survey ${ }^{32-36}$. Earlier studies also showed such a trend for medicinal plants subjected to AM inoculation with significant increase in growth and production of active secondary metabolites in some medicinal plants viz. Hemidesmus indicus, Gymnema sylvestris, Andrographis paniculata, A. alaba and Clerodendrum phlomidis 9, 37-39. Glomus aggregatum and Glomus fasciculatum were predominantly present and associated with all the Ocimum species. Among the seven AM fungal treatments, Pre-inoculation with Glomus fasciculatum improved the total seedling biomass, and nutrition uptake better in some medicinal plants also observed and reported by different workers ${ }^{40-44}$. So, the application of AM inoculum will play a very effective role for the commercial production as well as cultivation of medicinal plants which are rare, native to the Southern part of NE of Barak valley.

\section{CONCLUSION}

The following conclusions can be drawn from the above discussion

1. Medicinal plants are used as Traditional herbal medicines and are increasingly being used by people for primary health care system. Thus, the cultivation of medicinal plants should be increased to maintain a regular supply and to support their increasing demand by the use of Mycorrhizal fungi for sustainable medicinal plants productivity.

2. The beneficial role of rhizosphere AM fungi is to enhance the tolerance to various biotic and abiotic stresses, thereby increase the growth of medicinal plants. Mycorrhiza inoculated plants showed significant increase in growth and production of active secondary metabolites in some traditional medicinal plants. In order to develop a successful and sustainable protocol, the inoculum of AM fungi could be of great use for promoting growth and disease resistance in medicinal plants specifically found in Barak Valley, Assam for their great medicinal values by local tribes as well as for future commercial production.

3. In improving the socio-economic and cultural status of native people for collection of medicinal plants and their mycobionts like AM inoculum to increase the yield of medicinal plants along with their secondary metabolites to utilize these natural resources on a sustainable basis as a traditional and herbal medicine for the human welfare.

\section{ACKNOWLEDGEMENTS}

The authors wish to thank the University Grants Commission (UGC) New Delhi for providing financial support while carrying out this work. 


\section{REFERENCES}

1. Smith S.E. and Zhu, Y.G., Application of arbuscular mycorrhizal fungi: Potentials and challenges. In: Bio-Exploitation of Filamentous Fungi, edited by BP Stephen \& KD Hyde, Fungal Diversity Research Series,6; :291308(2001).

2. Gentili F. and Jumpponen A., Potential and possible uses of bacterial and fungal biofertilizers. In: Rai MK(ed) Handbook of Microbial biofertilizers, Haworth Press, Technology\& Engineering, New York,1-28 (2006).

3. Das A., Prasad R., Srivastava A., Giang H.P., Bhatnagar $\mathrm{K}$ and Varma, $\mathrm{A}$, Fungal siderophores: structure, functions and regulation. In: Soil Biology Volume 12 Microbial Siderophores, edited by A Varma \& SB Chincholkar, Springer-Verlag Berlin Heidelberg, 1-42(2007).

4. Tao G., Liu Z.Y., Hyde K.D. and Yu Z.N., Whole rDNA analysis reveals novel and endophytic fungi in Bletilla ochracea (Orchidaceae). Fungal Diversity, 33: 101-122 (2008).

5. Zhu G.S, Yu Z.N., Gui Y. and Liu Z.Y.,A novel technique for isolating orchid mycorrhizal fungi. Fungal Diversity, 33: 123-137 (2008).

6. Rinaldi A.C., Comandini $O$ and Kuyper T.W., Ectomycorrhizal fungal diversity: separating the wheat from the chaff, Fungal Diversity,33: 1-45(2008).

7. Tiwari $P$ and Adholeya A, Root organ culture of arbuscular mycorrhizal fungi: step towards reaching sustainable agriculture. Mycorrhiza News, 17 :15-17 (2005).

8. Chen J.H., The combined use of chemical and organic fertilizers and/or biofertilizer for crop growth and soil fertility. International Workshop on Sustained Management of the Soil-Rhizosphere System for Efficient Crop Production and Fertilizer Use. 16 -20 October 2006 Land Development Department, Bangkok 10900 Thailand, 1-11(2006).

9. Gupta V., Satyanarayana T and Garg S, General aspects of mycorrhiza. Mycorrhizal Biology, 27-44(2000).

10. Gianinazzi S. and Schupp H., Impact of arbuscular mycorrhizas on sustainable agriculture and natural ecosystem ALS. Birkhauser, Basel, Switzerland (1994).
11. http:// invam.caf.wvu.edu/

12. Raja P., Status of endomycorrhizal (AMF) biofertilizer in the global market. In: Handbook of Microbial Biofertilizers, edited by MK. Rai, Food products press, 395-416(2006).

13. Schwartz MW, Hoeksema JD, Gehring CA, Johnson NC, Klironomos JN, Abbott LK Pringle $A$, The promise and the potential consequences of the global transport of mycorrhizal fungal inoculum. Ecol. Lett., 9: 501-515(2006).

14. Douds Jr. D.D., Nagahashi G., Pfeffer P.E., Kayser, W.M. and Reider C. , On-farm production and utilization of arbuscular mycorrhizal fungus inoculum. C. J. Plant Sci., $85: 15-21(2005)$.

15. Yeasmin T., Zaman P., Rahman A., Absar N. and Khanum N.S.,Arbuscular mycorrhizal fungus inoculum production in rice plants. Afr. J. Agr. Res., 2 :463- 467(2007).

16. Kannaiyan S., Biofertilizers for sustainable crop production. In: Biotechnology of Biofertilizers, edited by S. Kannaiyan,Kluwer Academic Publishers,9-50(2002).

17. Azcon-Aquilar C. and Barea J.M., Arbuscular mycorrhizae and biological control of soilborne plant pathogens-an overview of the mechanisms involved. Mycorrhiza, 6 :457-464 (1996).

18. Akhtar S.M. and Siddiqui Z.A., Arbuscular mycorrhizal fungi as potential bioprotectantsagainst plant pathogens. In: Mycorrhizae: Sustainable Agriculture and Forestry, edited by ZA Siddiqui, MS Akhtar, M.S \& K Futai. Springer, 61-97(2008).

19. Johansson F.J., Paul R.L and Finlay D.R., Microbial interactions in the mycorrhizosphere and their significance for sustainable agriculture. FEMS Microbiol. Ecol., 48 :1-13 (2004).

20. Marin M., Arbuscular mycorrhizal inoculation in nursery practice. In: Handbook of Microbial Biofertilizers, edited by MK. Rai, Food products press, 289-324(2006).

21. Hart M.M. and Trevors J.T., Microbe management: application of mycorrhyzal fungi insustainable agriculture. Frontiers in Ecology and the Environment, 3 : 533539(2005). 
22. Kapoor R., Giri B. and Mukerji K.G., Glomus macrocarpum: a potential bioinoculant to improve essential oil quality and concentration in Dill (Anethum graveolens L.) and Carum (Trachyspermum ammi (Linn.) Sprague). World J. Microbiol. Biotechnol., 18: 459463(2002a).

23. Kapoor R., Sharma D. and Bhatnagar A.K., Arbuscular mycorrhizae in micropropagation systems and their potential applications. Scientia Horticulturae, 116 : 227-239(2008).

24. Aarle VIM, Olsson P.A., Soderstrom, Arbuscular mycorrhizal fungi respond to the substrate $\mathrm{pH}$ of their extraradical mycelium by altered growth and root colonization. New Phytol., 155 : 173-187 (2002).

25. Karthikeyan B., Joe1 M.M. and Jaleel C.A., Response of Some Medicinal Plants to Vesicular Arbuscular Mycorrhizal Inoculations. J. Sc. Res., 1 : 381-386 (2009).

26. Moose B., The influence of soil type and endogone strain on the growth of mycorrhizal plants in phosphate deficient soil. Rev. Ecol Biol Sol., 9: 529 (1972).

27. Barbhuiya A.R., Sharma G.D., Arunachalam A. and Deb S., Diversity and conservation of medicinal plants in Barak Valley, Northeast India. Ind. J. Trad. Knowledge, 8: 169175(2009).

28. Gupta M.L., Prasad A., Ram, M and Kumar S., Effect of the vesicular-arbuscular mycorrhizal (VAM) Fungus Glomus fasciculatum on the essential oil yield related characters and nutrient acquisition in the crops of different cultivars of menthol mint (Mentha arvensis) under field conditions. Bioresour Technol., 81 :77-79(2002).

29. Sampathkumar G.N, Prabakaran M. and Rajendra R.,Association of AM- fungi in some medicinal plants and its influence on growth. In: Organic farming and mycorrhizae in agriculture, I. K. Int. Pub. House Pvt. Ltd. New Delhi India, 101-106(2007).

30. Sampath K.G.,Murugesh S.,Rajendran A., Madhumati B. and Ganesh K, Association of VAM fungi with sesame and its influence on growth, Seasame and safflower Newsletter,17(2002).

31. Kumar G. and Murgesh S., A study on the VAM fungi improves growth of some medicinal plants, Advances in Plant Sciences ,15: 4346 (2002).

32. Szymon Z. and Janusz B., Medicinal plants as hosts of arbuscular mycorrhizal fungi and dark septate endophytes, Acta. Soc. Bot. Pol.,8 : 571-580(2009).

33. Ndiaye F., Manga, A. and Diagne-Leye G., Effects of rockphosphate and arbuscular mycorrhizal fungi on growth and nutrition of Sesbania sesban and Gliricidia sepium, Afri. J. Microbiol. Res., 3: 305-309(2009).

34. Jaleel CA, Gopi R, Panneerselvam $\mathrm{R}$,Alterations in non-enzymatic antioxidant components of Catharanthus roseus exposed to paclobutrazol, gibberellic acid and Pseudomonas fluorescens, Plant Omics, J., 2 : 30-40(2009).

35. Kapoor R Giri B. and Mukerji K.G., Mycorrhization of coriander (Coriandrum sativum $\mathrm{L}$.) to enhance the concentration and quality of essential oil, J. Sci. Food. Agri., 82 339-342(2002b).

36. Chatterjee S., Chatterjee S. and Dutta S., Cassia alata - an Useful Antimicrobial Agent, Med Aromat Plants, (2013)1.

37. Mathan C. Nisha and Rajeshkumar S., Effect of arbuscular mycorrhizal fungi on growth and nutrition of Wedilia chinensis (Osbeck) Merril, Ind. J. Sci. Technol.,3: 676-678 (2010).

38. Copetta A., Lingua G. and Berta G., Effects of three AM fungi on growth, distribution of glandular hairs, and essential oil production in Ocimum basilicum L. var. Genovese, Mycorrhiza,16 : 485-494(2006).

39. Trivedi P.C., Organic farming and mycorrhizae in agriculture. I. K. Int.Pub. House Pvt. Ltd. New Delhi India, 2007.

40. Kumar A., Mangla C., Aggarwal A. and Parkash V., Arbuscular Mycorrhizal fungi dynamics in the rhizospheric soil of five medicinal plant species, Middle East. J. Sci. Res., 6 : 281-288(2010).

41. Gaur S., Kaushik P., Analysis of vesicular arbuscular mycorrhiza associated with medicinal plants in Uttarkhand State of India, World Applied Science Journal, 14: 645-653 (2011).

42. Ingle R.W., Sarika M., Deshmukh V.V. and Joshi M., Association of vesicular arbuscular mycorrhizae with medicinal plant, Int. J.Sci. 
Environ., 2: 1265-1276 (2013).

43. Radhika K.P., Rodrigues BF, Arbuscular mycorrhizal fungal diversity in some commonly occurring medicinal plants of Western Ghats, Goa region. J. Forest Res., 21: 45-52 (2010).
44. Brundrett M.C., Mycorrhizal associations and other means of nutrition of vascular plants: understanding the global diversity of host plants by resolving conflicting information and developing reliable means of diagnosis, Plant Soil , 320: 7-77(2009). 